\title{
Multifocal osteonecrosis in systemic lupus erythematosus: case report and review of the literature
}

\author{
Luis D Fajardo-Hermosillo, Linnette López-López, Anaida Nadal, Luis M Vilá
}

Department of Medicine, Division of Rheumatology, University of Puerto Rico Medical Sciences Campus, San Juan, Puerto Rico

\section{Correspondence to} Dr Luis M Vilá, luis.vila2@upr.edu

\section{To cite: Fajardo-} Hermosillo LD, LópezLópez L, Nadal A, et al. BMJ Case Rep Published online: [please include Day Month Year] doi:10.1136/bcr-2013008980

\section{SUMMARY}

Osteonecrosis is a relatively common comorbidity in systemic lupus erythematosus (SLE), but avascular necrosis in multiple sites is unusual. Multifocal osteonecrosis is defined as osteonecrotic lesions affecting three or more separate anatomic sites. We report a case of a 24-year-old woman diagnosed with SLE when she presented with mucocutaneous, haematological and mild renal manifestations. Initially, she was treated with prednisone and hydroxychloroquine and her condition remained stable. Two years later, she developed severe bilateral pretibial ulcers intractable to immunosuppressive therapy and broad-spectrum antibiotics. MRI of both legs disclosed osteonecrosis of the distal tibia, proximal tibia, distal fibula and talus bilaterally. She had elevated anticardiolipin antibodies for which she was treated with chronic anticoagulation resulting in complete healing of the leg ulcers and no further episodes of osteonecrosis. In addition to this case, we review the demographic, clinical and pharmacological features of 14 cases reported in the literature.

\section{BACKGROUND}

Osteonecrosis $(\mathrm{ON})$ is the cellular death of bone components due to interruption of blood supply, resulting in pain, bone destruction and loss of function. ${ }^{1}$ Some of the mechanisms involved include vascular occlusion, ischaemia, altered fat metabolism, intravascular coagulation of the interosseous microcirculation, elevated intracortical pressure, mechanical stress, primary cell death and inhibition of angiogenesis. ${ }^{1} \mathrm{ON}$ is associated with multiple medical conditions and risk factors including trauma, autoimmune connective tissue diseases, renal disease, coagulation and haematological disorders, metabolic disorders, infections, alcohol abuse, smoking and the use of corticosteroids (CS) and cytotoxic agents, among others. ${ }^{1-3}$

Systemic lupus erythematosus (SLE) is a chronic, multisystemic, autoimmune disease of unknown aetiology that mainly affects women of childbearing age. CS are the first-line treatment, but chronic exposure often results in substantial morbidity and mortality. One of the several long-term adverse events of this agent is ON. ${ }^{1-3} \mathrm{ON}$ in SLE usually occurs in young individuals, with a prevalence ranging from $3 \%$ to $30 \% .^{145}$ The femoral head is the most commonly affected location followed by the knees, shoulders and ankles. ${ }^{125}$ Most patients have pain in the affected site, but up to $33 \%$ have asymptomatic ON. ${ }^{6}$ MRI is the gold standard diagnostic method to detect both symptomatic and silent ON. $^{6}$

$\mathrm{ON}$ in multiple sites is rare, being reported in $3.3 \%$ of patients with $\mathrm{ON}^{2}$ Multifocal ON is defined as the presence of osteonecrotic lesions in three or more separate anatomic sites. Chronic exposure to corticosteroid therapy is the most common risk factor (91-94\%). ${ }^{2}$ In a study of patients with multifocal ON, $38 \%$ had a diagnosis of SLE. ${ }^{2}$ However, there are limited data with regard to the clinical or laboratory manifestations in this group of patients. Few cases of multifocal $\mathrm{ON}$ in SLE have been reported in the literature. Here, we describe an additional case and review the demographic, clinical and pharmacological features of other published cases.

\section{CASE PRESENTATION}

A 24-year-old Puerto Rican woman was diagnosed with SLE in December 2005 when she presented with malar rash, discoid lesions, photosensitivity, haemolytic anaemia, thrombocytopaenia, leukopaenia, mild proteinuria, C3 and C4 hypocomplementaemia, and positive antinuclear (ANA), anti-dsDNA, anti-Ro and anti-RNP antibodies. Initially, she was treated with prednisone and hydroxychloroquine and her condition remained stable for 2 years.

In February 2008, she presented with general malaise, fever, severe haemolytic anaemia and possible vasculitis manifested by bilateral stage 2 pretibial leg ulcers. She was treated with broad-spectrum antibiotics, intravenous cyclophosphamide (4 pulses of $500 \mathrm{mg}$ for a cumulative dose of $2 \mathrm{~g}$ ) and high-dose methylprednisolone followed by high-dose prednisone (60 mg daily) with a gradual tapering down of the dosage. Mycophenolate mofetil was added after cyclophosphamide therapy, but it was discontinued because of severe gastrointestinal intolerance. Instead, azathioprine $100 \mathrm{mg}$ daily was started.

Three months later, she was hospitalised because of a worsening of the pretibial leg ulcers despite immunosuppressive treatment, multiple oral antibiotic courses and local care by the enterostomal service. She had severe pain in both of the lower extremities. Examination revealed deep-bilateral pretibial leg ulcers (figure 1A) which measured 2-3 cm in diameter. They had erythematosus borders and fetid purulent secretions. Distal pulses were normal. No Raynaud's phenomenon or livedo reticularis was evident. She had no other clinical signs of active lupus, and nor did she present with cushingoid features. 
(A)

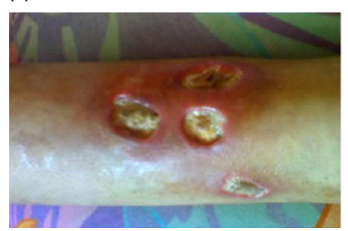

(B)

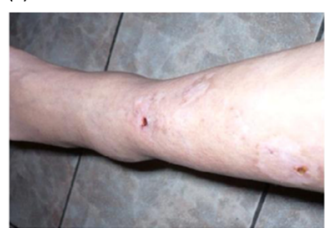

Figure 1 Leg ulcers (A) before and (B) 2 months after anticoagulation therapy.

\section{INVESTIGATIONS}

Laboratory tests revealed leucocytosis $(11400 / \mu \mathrm{l})$ and lymphopaenia $(800 / \mu \mathrm{l})$. She had no anaemia $(\mathrm{Hb}=13.2 \mathrm{~g} / \mathrm{dl})$ and the Westergren erythrocyte sedimentation rate was mildly elevated $(35 \mathrm{~mm} / \mathrm{h})$. The activated partial thromboplastin time test, prothrombin time test and international normalised ratio were normal. She had normal C3 and C4 levels. Work-up for antiphospholipid syndrome (APS) showed elevated IgM anticardiolipin (ACL) antibodies (20 units) but normal levels of IgG and IgA ACL antibodies.

Klebsiella pneumoniae and Enterococcus faecalis were isolated from deep wound culture of the infected leg ulcers. She was treated with intravenous vancomycin and piperacillin/tazobactam and hyperbaric oxygen therapy. Radiographs of the legs were normal. MRI of both legs was done for evaluation of possible osteomyelitis. Unexpectedly, it revealed areas of abnormal signal intensity within the medullar cavity of the distal tibia, proximal tibia, distal fibula and talus bilaterally, consistent with bone infarcts (figure 2).

\section{TREATMENT}

Owing to elevated ACL antibodies, persistent leg ulcers and ON as possible manifestations of APS, she was started on warfarin. She had no previous arterial or venous thrombosis, or miscarriages. Two months later, her leg ulcers healed completely (Figure 1B).

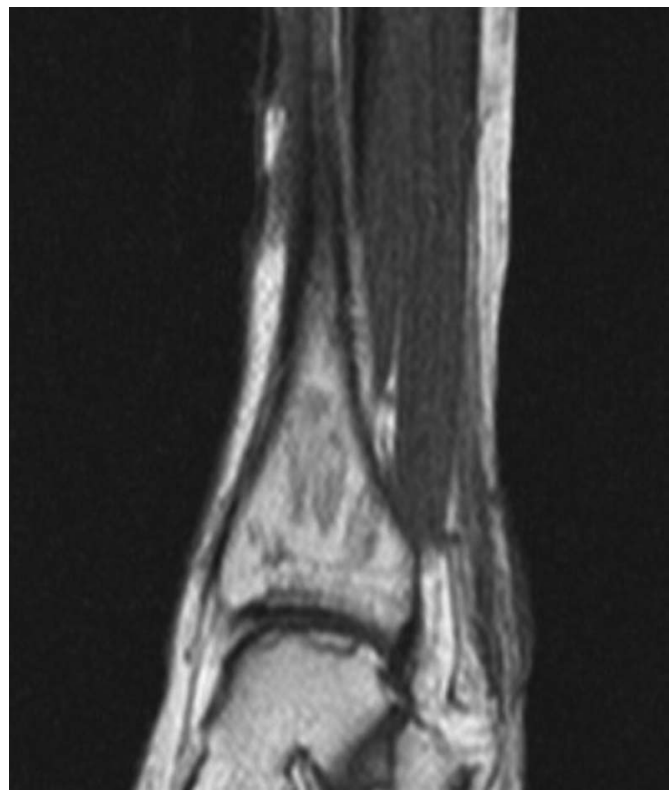

Figure 2 Geographic areas of decreased signal intensity within the medullar cavity of the left distal tibia and talus, consistent with osteonecrosis.

\section{OUTCOME AND FOLLOW-UP}

ACL antibodies were repeated 3 months and 3 years later. The levels of IgM ACL antibodies persisted in being elevated (28 and 25 units, respectively) and the IgG and IgA ACL antibodies remained normal. The lupus anticoagulant test and anti- $\beta 2$ glycoprotein I antibodies were negative.

Prednisone was gradually tapered down to $10 \mathrm{mg}$ daily and she was kept on hydroxychloroquine, azathioprine and warfarin. The patient has remained stable without further complications for 4 years.

\section{DISCUSSION}

Although ON in SLE is a relatively common complication, involvement of multiple sites is rare. Few cases have been reported in the literature. The demographic, clinical and pharmacological features of the current case and 14 additional reports are summarised in table $1 .^{8-19}$ Of the 15 cases, 11 occurred in women, with ages ranging from 17 to 60 years (mean 31.6 10.9 years, median 29.0 years). Most patients were 35 years of age or younger $(n=11)$. The time interval between the diagnosis of SLE and the occurrence of multifocal $\mathrm{ON}$ varied between 1 and 20 years (mean 6.1 \pm 5.5 years, median 3 years). The most common lupus manifestations were mucocutaneous $(n=8)$, renal $(n=7)$, haematological $(n=6)$, serosal $(n=6)$ and articular $(n=2)$. ANA and anti-dsDNA antibodies were observed in the majority of patients, anti-Ro antibodies in five and anti-RNP and anti-Smith antibodies in three patients. Antiphospholipid antibodies were found in seven patients. All patients received CS, from low-dose to high-dose prednisone, to methylprednisolone pulses. Most were treated with other immunosuppressors/immunomodulators such as azathioprine $(n=7)$, cyclophosphamide $(n=4)$, hydroxychloroquine $(n=4)$ and mycophenolate mofetil $(n=3)$. The most frequent comorbidity was infection, including septic arthritis in four patients, and infected leg ulcers, osteomyelitis, pyomyositis and psoas and iliac abscess, one in each case. The number of sites of ON ranged from 4 to 28 . Eight patients had $\mathrm{ON}$ both in the upper and lower extremities and seven had ON solely in the lower extremities.

The factors associated with the occurrence of ON in SLE have been studied, but particularly for patients presenting with less than three affected sites. In these patients with non-multifocal involvement, $\mathrm{ON}$ tends to occur in young patients, and usually in the first 5 years after SLE onset. Pleural effusion, nephritis, anaemia, Raynaud's phenomenon, arthritis, myositis, antiphospholipid antibodies, anti-Ro and anti-RNP antibodies and exposure to CS and cytotoxic agents have been associated with ON. ${ }^{3-5}$ Moreover, disease activity has been reported as the main risk factor for ON. ${ }^{20}$ Hence, based on the current literature review, the clinical manifestations associated with multifocal $\mathrm{ON}$ appear to be similar to those with non-multifocal involvement.

The possible association of antiphospholipid antibodies with multifocal ON reported here and in other cases is noteworthy. Our patient only had mild elevation of IgM ACL antibodies and negative tests for $\operatorname{IgG}$ and $\operatorname{IgA} \mathrm{ACL}$ antibodies, anti- $\beta 2$-glycoprotein I antibodies and a lupus anticoagulant test, which are more specific for APS than IgM ACL antibodies. Nonetheless, the presence of IgM ACL antibodies together with a complete healing of deep skin ulcers and no further episodes of ON after therapy with warfarin is suggestive of a diagnosis of APS. Interestingly, in a study of patients with primary APS, MRI of the hips disclosed ON in $20 \%$ of cases. None of these patients received treatment with $\mathrm{CS}^{21}$ In fact, ON might represent a clinical feature of APS, and antiphospholipid antibodies may play a role in the pathogenesis of $\mathrm{ON}$, even in the absence 
Table 1 Demographic, clinical and pharmacological treatments of SLE patients presenting with multifocal osteonecrosis

\begin{tabular}{|c|c|c|c|c|c|c|c|}
\hline $\begin{array}{l}\text { Authors/year } \\
\text { of publication }\end{array}$ & $\begin{array}{l}\text { Age } \\
\text { (years/ } \\
\text { gender) }\end{array}$ & $\begin{array}{l}\text { Time from SLE } \\
\text { diagnosis to } \\
\text { occurrence of } \\
\text { osteonecrosis (years) }\end{array}$ & Cumulative clinical manifestations & Autoantibodies & $\begin{array}{l}\text { Cortocosteroid treatment } \\
\text { (maximum dose) and other } \\
\text { immunosuppressor agents }\end{array}$ & Comorbidities & Osteonecrosis sites \\
\hline $\begin{array}{l}\text { Ruderman and } \\
\text { McCarty/1964 }\end{array}$ & 27/female & 5 & $\begin{array}{l}\text { Malar rash, oral ulcers, } \\
\text { photosensitivity, polyarthritis, serositis } \\
\text { and proteinuria }\end{array}$ & Not available & PRN 40 mg/day & & $\begin{array}{l}6 \text { sites: bilateral humeral heads, } \\
\text { bilateral femoral heads, right medial } \\
\text { femoral condyle and left talus }\end{array}$ \\
\hline 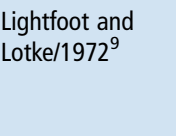 & $30 /$ male & 2 & $\begin{array}{l}\text { Polyarthritis and diffuse proliferative } \\
\text { glomerulonephritis }\end{array}$ & $\begin{array}{l}\text { ANA } \\
\text { Anti-dsDNA }\end{array}$ & $\begin{array}{l}\text { PRN } 60 \mathrm{mg} / \mathrm{day} \\
\text { CYC } 50 \mathrm{mg} / \mathrm{day}\end{array}$ & & $\begin{array}{l}17 \text { sites: bilateral metacarpal heads, } \\
\text { right lunate, bilateral femoral heads, } \\
\text { bilateral medial tibial plateaus and } \\
\text { bilateral taluses }\end{array}$ \\
\hline Darlington $^{10}$ & 60/female & 10 & $\begin{array}{l}\text { Polyarthritis, serositis, leukopaenia, } \\
\text { thrombocytopaenia and proximal } \\
\text { myopathy }\end{array}$ & $\begin{array}{l}\text { ANA } \\
\text { Anti-dsDNA }\end{array}$ & $\begin{array}{l}\text { PRN } 60 \mathrm{mg} / \mathrm{day} \\
\text { AZA } 100 \mathrm{mg} / \text { day }\end{array}$ & & $\begin{array}{l}12 \text { sites: bilateral metacarpal heads and } \\
\text { carpal bones, bilateral humeral heads, } \\
\text { right glenoid surface, bilateral medial } \\
\text { femoral condyles and left talus }\end{array}$ \\
\hline $\begin{array}{l}\text { Fishel et all } \\
1987^{11}\end{array}$ & 29/female & 2 & $\begin{array}{l}\text { Polyarthralgias, serositis, diffuse } \\
\text { proliferative glomerulonephritis and } \\
\text { Raynaud's phenomenon }\end{array}$ & ANA & $\begin{array}{l}\text { PRN } 60 \mathrm{mg} / \text { day } \\
\text { AZA }\end{array}$ & & $\begin{array}{l}13 \text { sites: right carpals bones, right } \\
\text { femoral head and medial femoral } \\
\text { condyle, left distal tibia, right tarsal } \\
\text { navicular and bilateral metatarsal heads }\end{array}$ \\
\hline $\begin{array}{l}\text { Markov et all } \\
1996^{12}\end{array}$ & 32/female & 11 & $\begin{array}{l}\text { Discoid rash, polyarthralgias, } \\
\text { pleuropericarditis, focal proliferative } \\
\text { glomerulonephritis and vasculitic rash }\end{array}$ & $\begin{array}{l}\text { ANA } \\
\text { Anti-dsDNA } \\
\text { Anti-Ro }\end{array}$ & $\begin{array}{l}\text { PRN } 60 \mathrm{mg} / \text { day } \\
\text { AZA }\end{array}$ & $\begin{array}{l}\text { Pre-eclampsia and amniotic fluid } \\
\text { embolism } \\
\text { Left knee septic arthritis (Enterococcus } \\
\text { faecalis) }\end{array}$ & $\begin{array}{l}6 \text { sites: bilateral femoral heads, bilateral } \\
\text { femoral condyles and proximal tibias }\end{array}$ \\
\hline $\begin{array}{l}\text { Guillaume et all } \\
1998^{13}\end{array}$ & $17 /$ male & 1 & Polyarthritis & $\begin{array}{l}\text { ANA } \\
\text { Anti-dsDNA } \\
\text { Anti-aPL } \\
\text { (IgG aCL) }\end{array}$ & $\begin{array}{l}\text { MPSL } 24 \text { mg/day } \\
\text { AZA }\end{array}$ & & $\begin{array}{l}28 \text { sites: left elbow, right femoral head, } \\
\text { bilateral medial femoral condyles, tibial } \\
\text { plateaus, epiphyses and diaphyses } \\
\text { bilaterally, taluses and tarsal scaphoids, } \\
\text { cuneiforms and calcanea bilaterally }\end{array}$ \\
\hline \multirow[t]{3}{*}{$\begin{array}{l}\text { Galindo et all } \\
2005^{14}\end{array}$} & 27/female & 3 & $\begin{array}{l}\text { Malar rash, oral ulcers, polyarthralgias, } \\
\text { diffuse proliferative glomerulonephritis, } \\
\text { haemolytic anaemia, leukopaenia, } \\
\text { lymphopaenia and Raynaud's } \\
\text { phenomenon }\end{array}$ & $\begin{array}{l}\text { ANA } \\
\text { Anti-dsDNA } \\
\text { Anti-Sm } \\
\text { Anti-aPL }\end{array}$ & $\begin{array}{l}\text { MPSL } 20 \mathrm{mg} / \text { day } \\
\text { Intravenous CYC }\end{array}$ & $\begin{array}{l}\text { Catheter infection and septic arthritis } \\
\text { both knees (Methicillin-resistant } \\
\text { Staphylococcus aureus) }\end{array}$ & $\begin{array}{l}4 \text { sites: bilateral distal femoral } \\
\text { epiphyses and proximal tibial epiphyses }\end{array}$ \\
\hline & 38/female & 2 & $\begin{array}{l}\text { Malar rash, photosensitivity, } \\
\text { polyarthritis, anaemia, leukopaenia, } \\
\text { lymphopaenia and thrombocytopaenia }\end{array}$ & $\begin{array}{l}\text { ANA } \\
\text { Anti-dsDNA } \\
\text { Anti-Ro } \\
\text { Anti-aPL }\end{array}$ & $\begin{array}{l}\text { MPSL } 1 \mathrm{mg} / \mathrm{kg} / \mathrm{day} \\
\text { Intravenous CYC }\end{array}$ & $\begin{array}{l}\text { Splenic, hepatic and subcutaneous } \\
\text { abscesses and right coxofemoral septic } \\
\text { arthritis (methicillin-sensitive } S \text {. } \\
\text { aureus) }\end{array}$ & $\begin{array}{l}6 \text { sites: shoulders, bilateral femoral } \\
\text { heads and knees. }\end{array}$ \\
\hline & 27/female & 3 & $\begin{array}{l}\text { Malar rash, polyarthritis, pericardial } \\
\text { effusion, lymphopaenia, Raynaud's } \\
\text { phenomenon }\end{array}$ & $\begin{array}{l}\text { ANA } \\
\text { Anti-dsDNA } \\
\text { Anti-Sm } \\
\text { Anti-RNP } \\
\text { Anti-aPL }\end{array}$ & MPSL 1 mg/kg/day & $\begin{array}{l}\text { Septic arthritis of both knees, right } \\
\text { olecranal septic bursitis, right leg } \\
\text { pyomyositis with bilateral psoas and } \\
\text { iliac abcesses, and left femoral } \\
\text { osteomyelitis }\end{array}$ & $\begin{array}{l}5 \text { sites: left elbow, bilateral humeral } \\
\text { heads, right femoral head and talus }\end{array}$ \\
\hline $\begin{array}{l}\text { Cavallasca et all } \\
2005^{15}\end{array}$ & 25/female & 13 & Polyarthritis & $\begin{array}{l}\text { ANA } \\
\text { Anti-dsDNA } \\
\text { Anti-Ro } \\
\text { Anti-Sm } \\
\text { Anti-RNP }\end{array}$ & $\begin{array}{l}\text { PRN } 60 \mathrm{mg} / \text { day } \\
\text { AZA }\end{array}$ & $\begin{array}{l}\text { Systemic sclerosis with dysphagia, } \\
\text { pulmonary fibrosis, Raynaud's } \\
\text { phenomenon and livedo reticularis }\end{array}$ & $\begin{array}{l}6 \text { sites: right distal tibia, bilateral } \\
\text { taluses, left calcaneus, and bilateral } \\
\text { navicular bones }\end{array}$ \\
\hline
\end{tabular}


Table 1 Continued

\begin{tabular}{|c|c|c|c|c|c|c|c|}
\hline $\begin{array}{l}\text { Authors/year } \\
\text { of publication }\end{array}$ & $\begin{array}{l}\text { Age } \\
\text { (years/ } \\
\text { gender) }\end{array}$ & $\begin{array}{l}\text { Time from SLE } \\
\text { diagnosis to } \\
\text { occurrence of } \\
\text { osteonecrosis (years) }\end{array}$ & Cumulative clinical manifestations & Autoantibodies & $\begin{array}{l}\text { Cortocosteroid treatment } \\
\text { (maximum dose) and other } \\
\text { immunosuppressor agents }\end{array}$ & Comorbidities & Osteonecrosis sites \\
\hline $\begin{array}{l}\text { García-Miguel } \\
\text { et al/2006 }\end{array}$ & $35 /$ male & 8 & Photosensitivity and polyarthritis & $\begin{array}{l}\text { ANA } \\
\text { Anti-dsDNA } \\
\text { Anti-Ro } \\
\text { Anti-aPL }\end{array}$ & $\begin{array}{l}\text { PRN } 5 \mathrm{mg} / \text { day } \\
\text { HCQ } 400 \mathrm{mg} / \text { day }\end{array}$ & $\begin{array}{l}\text { Alcohol abuse } \\
\text { Cigarette smoking }\end{array}$ & $\begin{array}{l}8 \text { sites: bilateral femoral heads and } \\
\text { condyles, bilateral tibial epiphyses and } \\
\text { diaphyses }\end{array}$ \\
\hline $\begin{array}{l}\text { Salesi et all } \\
2010^{17}\end{array}$ & 21/female & 3 & $\begin{array}{l}\text { Malar rash, photosensitivity, } \\
\text { polyarthritis, pericardial effusion, } \\
\text { leukopaenia and proteinuria }\end{array}$ & $\begin{array}{l}\text { ANA } \\
\text { Anti-dsDNA } \\
\text { aCL }\end{array}$ & $\begin{array}{l}\text { PRN } \\
\text { HCQ } \\
\text { MMF } \\
\text { AZA }\end{array}$ & Unknown & $\begin{array}{l}4 \text { sites: bilateral distal femur and } \\
\text { bilateral hips }\end{array}$ \\
\hline $\begin{array}{l}\text { Greenhagen } \\
\text { et al/2012 }\end{array}$ & 40/male & 20 & Unknown & Unknown & $\begin{array}{l}\text { PRN } \\
\text { HCQ } \\
\text { MMF }\end{array}$ & $\begin{array}{l}\text { End-stage renal disease } \\
\text { Hypertension } \\
\text { Hyperlipidaemia } \\
\text { Raynaud's phenomenon } \\
\text { CNS vasculitis }\end{array}$ & $\begin{array}{l}5 \text { sites: bilateral navicular, bilateral } \\
\text { medial cuneiform and right } \\
\text { intermediate cuneiform bone }\end{array}$ \\
\hline $\begin{array}{l}\text { Stroh et all } \\
2012^{19}\end{array}$ & 45/female & Unknown & Unknown & Unknown & Unknown & Corticosteroid use & $\begin{array}{l}10 \text { sites: bilateral hips, knees, ankles, } \\
\text { shoulders and right wrist }\end{array}$ \\
\hline $\begin{array}{l}\text { Current report/ } \\
2013\end{array}$ & 21/female & 3 & $\begin{array}{l}\text { Malar rash, discoid rash, } \\
\text { photosensitivity, proteinuria, } \\
\text { haemolytic anaemia, leukopaenia, } \\
\text { thrombocytopaenia and livedo } \\
\text { reticularis }\end{array}$ & $\begin{array}{l}\text { ANA } \\
\text { Anti-dsDNA } \\
\text { Anti-Ro } \\
\text { Anti-RNP } \\
\text { Anti-aPL } \\
\text { (IgM aCL) }\end{array}$ & $\begin{array}{l}\text { MPSL intravenous pulse } \\
\text { PRN } 40 \text { mg/day } \\
\text { Intravenous CYC } \\
\text { MMF } \\
\text { AZA } \\
\text { HCO }\end{array}$ & $\begin{array}{l}\text { Bilateral pretibial leg ulcers (Klebsiella } \\
\text { pneumoniae and Enterococcus } \\
\text { faecalis) }\end{array}$ & $\begin{array}{l}8 \text { sites: bilateral proximal and distal } \\
\text { tibias, bilateral distal fibulas and } \\
\text { taluses }\end{array}$ \\
\hline
\end{tabular}

ACL, anticardiolipin antibodies isotype IgG; ANA, antinuclear antibodies; Anti-aPL, antiphospholipid antibodies; Anti-RNP, ribonucleoprotein antibodies; Anti-Ro, Anti-SSA antibodies; Anti-Sm, anti-Smith antibodies; AZA, azathioprine; CYC, cyclophosphamide; HCQ, hydroxychloroquine; MMF, mycophenolate mofetil; MPSL, methylprednisolone; PRN, prednisone; SLE, systemic lupus erythematosus. 
of other predisposing factors. Thus, in asymptomatic patients with antiphospholipid antibodies, ON might be underdiagnosed, precluding an early intervention.

All lupus patients described in the literature having multifocal ON received CS and most were treated with cytotoxic agents. CS are the most common cause of non-traumatic ON as well the most consistent factor associated with the development of $\mathrm{ON}$ in SLE. ${ }^{3}{ }^{6}$ In a case-control study in SLE patients, Prasad et $a l^{5}$ found that CS use was the major factor linked with the development of ON. The duration of corticosteroid therapy, total cumulative dose and highest daily dose have been independently associated with the development of $\mathrm{ON}^{3}{ }^{20} \mathrm{CS}$ may induce $\mathrm{ON}$ by increasing the amount of fat within the bone, elevating the intramedullar pressure and consequently producing sinusoidal collapse. But in general, the effect of corticosteroids at the cellular level and their influence on the immune system is one of the principally proposed mechanisms for the development of ON. Also, apoptosis of the osteoblasts and osteoclasts, a decreased bone turnover and a decreased survival of osteocytes appear to be important mechanisms for inducing ON. ${ }^{22}$

Infection represents a major cause of morbidity and mortality in lupus patients. ${ }^{11}$ Our case, as well as other reports, suggests an association of soft tissue and joint infections with multifocal ON. However, it is not clear whether the local infection predisposes to $\mathrm{ON}$ or if the bone necrotic tissue renders the affected area susceptible to infection. ON followed by infection has been rarely described in patients with SLE, Salmonella species being the most commonly recognised agent, followed by Gram-positive cocci. ${ }^{11} 13$ The poorly vascularised and necrotic bone allows chronic bacterial growth that can increase the release of metalloproteinases, causing further destruction of the bone matrix structure. ${ }^{11} 13$

Of note, this case highlights the potential benefit of chronic anticoagulation as a therapeutic option in SLE patients with concomitant $\mathrm{ON}$ and antiphospholipid antibodies. Our patient did not present further episodes of $\mathrm{ON}$ after 4 years of follow-up. Although there is insufficient evidence to support chronic anticoagulation in these patients, a tendency to prevent symptomatic ON in SLE patients treated with warfarin has been reported. $^{23}$

In summary, the present case and others suggest that SLE patients developing multifocal $\mathrm{ON}$ tend to be young, have several SLE clinical manifestations and serological abnormalities, and most have been exposed to CS and cytotoxic agents. In addition, the possible association of antiphospholipid antibodies as well as joint/soft tissue infections should alert physicians that these patients might be at higher risk for multifocal ON. Nonetheless, these observations must be confirmed in larger and prospective studies with a more rigorous methodology.

\section{Learning points}

- Osteonecrosis $(\mathrm{ON})$ is a relatively common comorbidity in systemic lupus erythematosus (SLE), but avascular necrosis in multiple sites is unusual.

- SLE patients developing multifocal ON tend to be young, have several SLE clinical manifestations and serological abnormalities, and most have been exposed to corticosteroids and cytotoxic agents.

- Corticosteroid therapy, antiphospholipid antibodies and joint/ soft tissue infections seem to be associated with multifocal ON in SLE patients.
Contributors LDF-H, LL-L, AN and LMV substantially contributed to acquisition of data, drafting the article or evising it critically for important intellectual content and final approval of the version of the article to be published author.

\section{Competing interests None.}

Patient consent Obtained.

Provenance and peer review Not commissioned; externally peer reviewed.

\section{REFERENCES}

1 Assouline-Dayan Y, Chang C, Greenspan A, et al. Pathogenesis and natural history of osteonecrosis. Semin Arthritis Rheum 2002:32:94-124.

2 Collaborative Osteonecrosis Group. Symptomatic multifocal osteonecrosis. A multicenter study. Clin Orthop Relat Res 1999;369:312-26.

3 Calvo-Alén J, McGwin G, Toloza S, et al. Systemic lupus erythematosus in a multiethnic US cohort (LUMINA): XXIV. Cytotoxic treatment is an additional risk factor for the development of symptomatic osteonecrosis in lupus patients: results of a nested matched case-control study. Ann Rheum Dis 2006;65:785-90.

4 Abu-Shakra M, Buskila D, Shoenfeld Y. Osteonecrosis in patients with SLE. Clin Rev Allergy Immunol 2003;25:13-24.

5 Prasad R, Ibanez D, Gladman D, et al. The role of non-corticosteroid related factors in osteonecrosis $(\mathrm{ON})$ in systemic lupus erythematosus: a nested case-control study of inception patients. Lupus 2007;16:157-62.

6 Nagasawa K, Tada Y, Koarada S, et al. Very early development of steroid-associated osteonecrosis of femoral head in systemic lupus erythematosus: prospective study by MRI. Lupus 2005;14:385-90.

7 LaPorte DM, Mont MA, Mohan V, et al. Multifocal osteonecrosis. J Rheumatol 1998;25:1968-74.

8 Ruderman M, McCarty D. Aseptic necrosis in systemic lupus erythematosus. Report of a case involving six joints. Arthritis Rheum 1964;7:709-21.

9 Lightfoot R, Lotke P. Osteonecrosis of metacarpal heads in systemic lupus erythematosus. Value of radiostrontium scintimetry in differential diagnosis. Arthritis Rheum 1972;15:486-92.

10 Darlington LG. Osteonecrosis at multiple sites in a patient with systemic lupus erythematosus. Ann Rheum Dis 1985;44:65-6.

11 Fishel B, Caspi D, Eventov I, et al. Multiple osteonecrotic lesions in systemic lupus erythematosus. J Rheumatol 1987;14:601-4.

12 Markov G, Dobro J, Shankman S, et al. Enterococcal arthritis with avascular necrosis in a lupus patient. Br J Rheumatol 1996;35:595-7.

13 Guillaume MP, Brandelet B, Peretz A. Unusual high frequency of multifocal lesions of osteonecrosis in a young patient with systemic lupus erythematosus. $\mathrm{Br} \mathrm{J}$ Rheumatol 1998;37:1248-9.

14 Galindo M, Mateo I, Pablos JL. Multiple avascular necrosis of bone and polyarticular septic arthritis in patients with systemic lupus erythematosus. Rheumatol Int 2005:25:72-6.

15 Cavallasca JA, Laborde HA, Araujo MB, et al. Multiple avascular necrosis in a patient with systemic lupus erythematosus/systemic sclerosis overlap syndrome. Clin Rheumatol 2005;24:406-8.

16 García-Miguel J, Calvet-Fontova J, Maymó-Guarsch J, et al. Multifocal osteonecrosis in a patient with systemic lupus erythematosus. Med Clin (Barc) 2006;127:276.

17 Salesi M, Karimifar M, Mottaghi P, et al. A case of SLE with bilateral osteonecrosis and bone infarct in distal of femur. Rheumatology Int 2010;30:527-9.

18 Greenhagen RM, Crim BE, Shinabarger AB, et al. Bilateral osteonecrosis of the navicular and medial cuneiform in a patient with systemic lupus erythematosus: a case report. Foot Ankle Spec 2012;5:180-4.

19 Stroh DA, LaPorte DM, Marker DA, et al. Atraumatic osteonecrosis of the distal radius and ulna: case series and review. J Hand Surg Am 2012;37:134-41.

20 Fialho SC, Bonfá E, Vitule LF, et al. Disease activity as a major risk factor for osteonecrosis in early systemic lupus erythematosus. Lupus 2007;16:239-44.

21 Tektonidou MG, Malagari K, Vlachoyiannopoulos PG, et al. Asymptomatic avascular necrosis in patients with primary antiphospholipid syndrome in the absence of corticosteroid use: a prospective study by magnetic resonance imaging. Arthritis Rheum 2003:48:732-6.

22 Powell C, Chang C, Gershwin ME. Current concepts on the pathogenesis and natural history of steroid-induced osteonecrosis. Clin Rev Allergy Immunol 2011;41:102-13.

23 Nagasawa K, Tada Y, Koarada S, et al. Prevention of steroid-induced osteonecrosis of femoral head in systemic lupus erythematosus by anti-coagulant. Lupus 2006;15:354-7. 
Copyright 2013 BMJ Publishing Group. All rights reserved. For permission to reuse any of this content visit http://group.bmj.com/group/rights-licensing/permissions.

BMJ Case Report Fellows may re-use this article for personal use and teaching without any further permission.

Become a Fellow of BMJ Case Reports today and you can:

- Submit as many cases as you like

- Enjoy fast sympathetic peer review and rapid publication of accepted articles

- Access all the published articles

- Re-use any of the published material for personal use and teaching without further permission

For information on Institutional Fellowships contact consortiasales@bmjgroup.com

Visit casereports.bmj.com for more articles like this and to become a Fellow 